\title{
Genetic Relationships of Spanish Olive Cultivars Using RAPD Markers
}

\author{
A.Belaj, ${ }^{1}$ Z. Satovic, I. Trujillo, and L. Rallo \\ Departamento de Agronomía. ETSIAM. Universidad de Córdoba. Avenida \\ Ménendez Pídal s/n, Apdo 3048, 14080 Córdoba, Spain
}

Additional index words. Olea europaea L., DNA markers, genetic diversity, AMOVA

\begin{abstract}
Eighty-two Spanish olive cultivars from the World Germplasm Bank of the Centro de Investigación y Formación Agraria (CIFA) Alameda del Obispo in Cordoba (Spain) were analysed by RAPD markers to assess their genetic relatedness and to study patterns of genetic variation. The dendrogram based on unweighted pair group cluster analysis using Jaccard's index included two major groups that consisted mostly of cultivars from the southern and central part of Spain. Clustering together of cultivars from the Levante zone was also observed. The pattern of genetic variation among olive cultivars from three different Spanish zones (Levante, central and Andalusia) was analysed by means of the analysis of molecular variance (AMOVA). Although most of the genetic variability was attributable to differences of cultivars within each zone $(95.88 \%)$, significant $\phi$-values among zones $\left(\phi_{\mathrm{st}}=0.041 ; \boldsymbol{p}<0.001\right)$ suggested the existence of phenotypic differentiation. These results are consistent with the predominantly allogamous nature of Olea europaea L. species. Significant values of $\phi_{\text {st }}$ for the pair Andalusia/Levante indicate the presence of differentiation. The negative value of $\phi_{\mathrm{st}}$ observed in the case of the Andalusia/central pair suggests that some varieties from central Spain are more similar to the Andalusian ones than to the varieties of their own geographic area, and vice versa.
\end{abstract}

Olive (Olea europaea L.) is one of the oldest agricultural tree crops in Spain with remarkable cultural and economic importance. Spanish olive germplasm is estimated to include $\approx 262$ cultivars (Barranco, 1997). Most cultivars are old and were locally selected for traditional dry land agriculture presenting in this way unsuitable traits for a sustainable olive industry (Barranco and Rallo, 1984; Barranco, 1997). A breeding program for developing cultivars appropriate for modern production systems using intraspecific crosses started in 1991 at the Department of Agronomy at Cordoba's University. A detailed knowledge of the amount and the distribution of genetic variability among existing cultivars is being pursued to broaden the genetic base of new cultivars and to use the available olive germplasm fully. Modern commercial orchards are dominated by a few well-known cultivars for commercial production (Barranco, 1997), which may lead to a potential loss of local cultivars and germplasm erosion. New cultivars from breeding programs may further restrict the genetic variability.

DNA markers can provide more accurate

Received for publication 29 July 2002. Accepted for publication 26 July 2003. Contribution from the Department of Agronomy, University of Cordoba, Cordoba, Spain. Faculty of Agriculture. University of Zagreb. Department of Seed Science and Technology. Svetosimunska 25, 10000 Zagreb, Croatia. Thanks are due to D. Barranco and J. Tous for their valuable suggestions. We acknowledge the contribution of the World Olive Germplasm Bank of Cordoba for the accomplishment of this work. This research was funded by the INIA (Instituto Nacional de Investigación y Tecnología Agraria y Alimentaria del MAPA), project CAO 98-001-C3-1 and by an Europian Union project (FAIR-CT95-0689). A. Belaj had a PhD grant from the Agencia Española de Cooperación Internacional (AECI), Spain

${ }^{1}$ Corresponding author; e.mail ag2belay@uco.es. estimates of genetic diversity and genetic relationships than other methods such as morphological description or/and isozymes (Barranco and Rallo, 1984; Trujillo, 1992; Trujillo et al., 1995). The present research is part of a larger RAPD analysis of Spanish olive Germplasm. Our objectives were to determine the genetic relationships among cultivars, and study patterns of variation shown by olive cultivars from different Spanish olive growing zones.

\section{Materials and Methods}

Plant material and DNA extraction. Eighty-two Spanish olive cultivars from the World Germplasm Bank of the CIFA Alameda del Obispo in Cordoba, Spain, were studied. These cultivars and their zone of difussion are presented in Table 1. Genomic DNA was spring of 1999, following the method described by Belaj et al. (2001).

Polymerase chain reaction. Thirteen decamer oligonucleotides from kits A, F, I, J, K, P, Q, and X from Operon Technologies (Alameda, Calif.) were used for PCR amplifications. DNA was amplified in $20 \mu \mathrm{L}$ reaction mixtures containing 20 to $40 \mathrm{ng}$ of template DNA, 0.05 U polymerase AmpliTaq DNA Stoffel fragment from Applied Biosystems (Foster City, Calif.), 0.75 mm each of dNTP from Roche (Basel, Switzerland), $20 \mu \mathrm{M}$ of the primer, 25 $\mathrm{mm} \mathrm{MgCl}_{2}, 50 \mathrm{~mm} \mathrm{KCl}$, and $10 \mathrm{~mm}$ Tris- $\mathrm{HCl}$ ( $\mathrm{pH}$ 8.3). The reactions were performed in a thermal cycler (GeneAmp PCR System 9600) from Applied Biosystems programmed for 1 cycle of 1 min at $94^{\circ} \mathrm{C}$ followed by 40 cycles: of $20 \mathrm{~s}$ at $94{ }^{\circ} \mathrm{C}, 20 \mathrm{~s}$ at $35^{\circ} \mathrm{C}$, and $2 \mathrm{~min}$ at $72{ }^{\circ} \mathrm{C}$, for denaturing, primer annealing, and extension, respectively. The last cycle was followed by incubation for $6 \mathrm{~min}$ at $72^{\circ} \mathrm{C}$. All the reactions were conducted three times using extracted from young leaf tissue collected in
DNA of different extractions and different lots of the AmpliTaq DNA polymerase.

Separation and visualisation of the amplification products. Amplification products were separated on polyacrylamide gels of 18 $\times 16 \mathrm{~cm}$ containing $10 \%$ acrylamide, $0.126 \%$ piperazine diacrylamide crosslinker in 0.375 м Tris- $\mathrm{HCl}, \mathrm{pH} 8.8$, using Tris glycine $(0.025$ $\mathrm{M}$ Tris, and $0.192 \mathrm{M}$ glycine) at $30 \mathrm{~mA}$ per gel for $3.5 \mathrm{~h}$. The DNA was visualized by silver staining as described by Bassam et al. (1991). Gels were photographed using a digital camera (Kodak DC 120). Molecular sizes of the amplification products were estimated using a 123 base pair (bp) DNA ladder from Sigma (St. Louis, Mo.).

Data analysis. RAPD bands were scored as 1 (present) or 0 (absent) in a binary matrix for each primer. A conservative criterion for the selection of bands was used. Only reproducible and well-defined bands in each of the three replications were considered as potential polymorphic markers.

Jaccard's (1908) coefficient of similarity was calculated, and the cultivars were grouped by cluster analysis using the unweighted pairgroup method (UPGMA). The computer program used was NTSYS-pc version 2.02 (Rohlf, 1998). Cophenetic correlation coefficient was calculated, and Mantel's test (Mantel, 1967) was performed to check the goodness of fit of a cluster analysis to the matrix on which was based.

A one way AMOVA was performed for the study of the partitioning of RAPD variation among and within olive growing Spanish zones: 1) The zone of Levante (northeastern Spain) 2) central Spanish zone and 3) Andalusian (southern Spain) zone (Fig. 1). Significance levels of the variance were obtained with tests including 1000 permutations for each analysis

The Analyses of Molecular Variance (AMOVA; Excoffier et al., 1992) were carried out on the RAPD data using the WINAMOVA 1.55 program (Excoffier, 1992). A matrix of Jaccard distances between RAPD phenotypes was constructed, and the AMOVA variance components were used as estimates of molecular diversity. The AMOVA procedure provides an estimate $\phi_{\mathrm{s}}$, of population differentiation, which is equivalent to a F-st statistic when the degree of relatedness among the genetic variants is evaluated. To obtain a distance matrix, $\phi_{\text {st }}$ values between any two populations (in our case-zones) were interpreted as the inter-population distance average between any two populations (Gustine and Huff, 1999; Huff, 1997).

Homogeneity of intrapopulation molecular variances (homoscedasticity) was tested using the HOMOVA procedure (Barlett's test) also implemented in WINAMOVA (Stewart and Excoffier, 1996). Barlett's statistic (Barlett, 1937) null distributions were obtained after 1000 permutations.

\section{Results}

Genetic relationships among olive cultivars. In total, 82 bands were scored for the 13 primers used giving an average of 6.3 bands 
Table 1. Cultivars analyzed with their register number (RN) in the collection as well as their zone of diffusion.

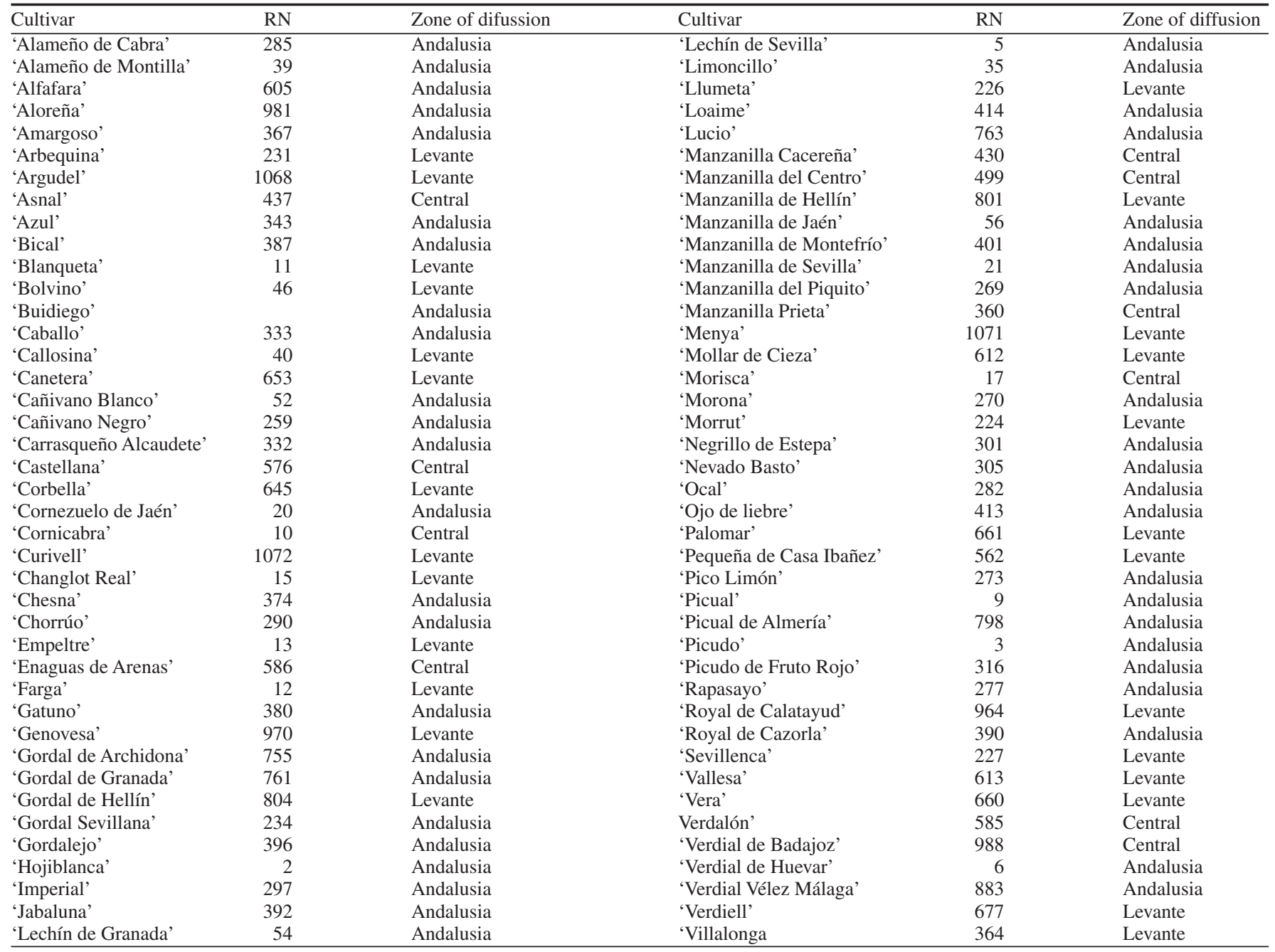

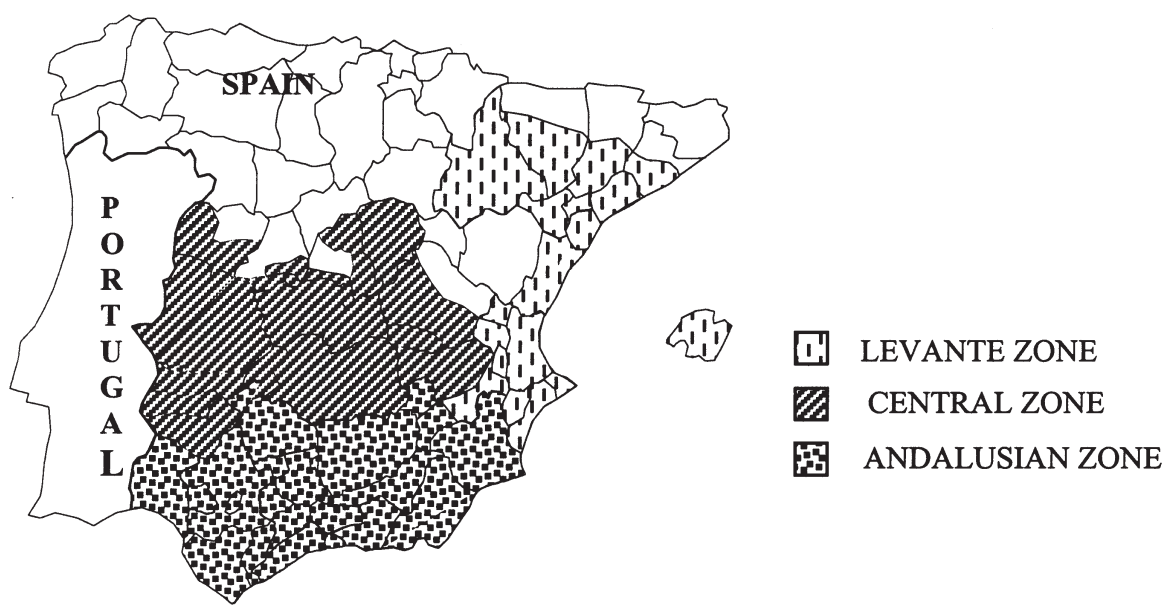

Fig. 1. Spanish olive growing zones classified for the study of the partitioning of RAPD variation by means of AMOVA analysis.

per primer. A relatively high range of similarity values between genotypes (data not shown) was observed, with most similarity values at $\approx 0.70$. The greatest similarity (0.96) was observed between the cultivars 'Mollar de Cieza' and 'Verdalón'. The lowest similarity values were obtained between 'Bolvino' and 'Llumeta' (0.20) and 'Canetera' and 'Blanqueta' (0.22). Cophenetic correlation coefficient between the ships between cultivars and their geographic origin.

Group I includes mostly cultivars from southern (Andalusia) and central Spain. For instance, cluster 01 includes 10 cultivars from Andalusia ('Chesna', 'Picual', 'Alameño de Cabra', 'Gordal de Archidona', 'Gatuno', 'Negrillo de Estepa', 'Lechín de Granada', 'Bical' 'Manzanilla de Sevilla', and 'Ocal') and two cultivars ('Alfafara' and 'Changlot Real') from Levante zone (northeastern Spain). Nine cultivars from Andalusia and central Spain ('Manzanilla de Montefrío', 'Carrrasqueño de Alcaudete', 'Manzanilla Prieta', 'Castellana', 'Ojo de Liebre', 'Nevado Basto', 'Pico Limón' 'Enagua de Arenas' and 'Verdial de Badajoz') together with three cultivars from Levante zone ('Curivell', 'Vera' and 'Gordal de Hellín') branched together to cluster 02. Cluster 03 included four Andalusian cultivars: 'Azul', 'Lucio' 'Cornezuelo de Jaen', and 'Loaime'.

The same tendency of clustering together of cultivars from southern and central Spain was also observed in Group II (cluster 04 to 06). However, there were exceptions, such as 'Mollar de Cieza', 'Farga', and 'Manzanilla de Hellín', which come from Levante zone. The seven subgroups that clustered independently at different coefficient values (cluster 07 to 13) 


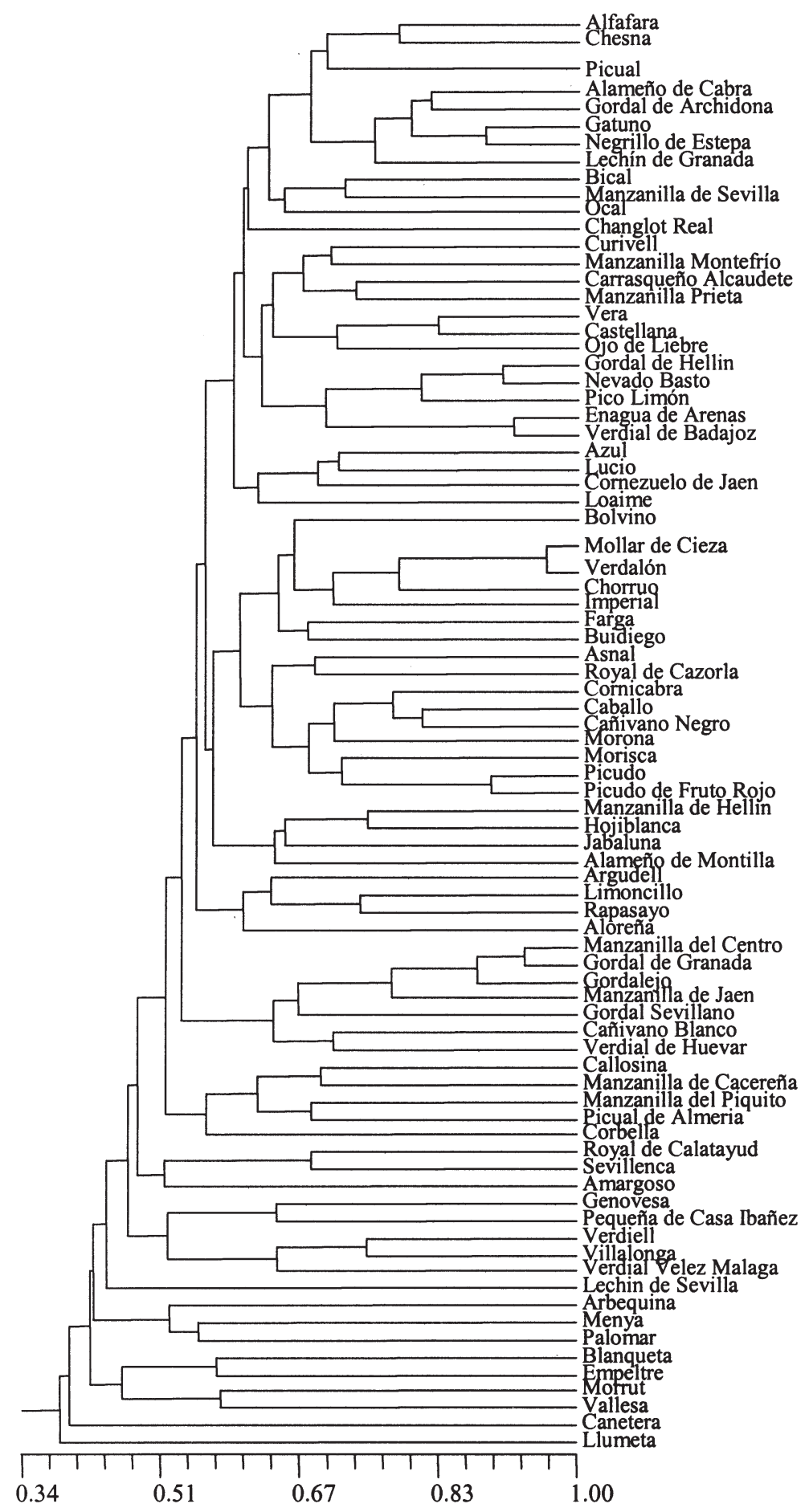

Cluster 02

Cluster 03

Cluster 04

Cluster 05

Cluster 06

Cluster 07

Cluster 08

Cluster 09

Cluster 10

Cluster 11

Cluster 12

Cluster 13

Fig. 2. Dendrogram of the Spanish cultivars using UPGMA clustering methods and Jaccard's index of similarity.

also showed a good association with geographic origin. Most cultivars that formed clusters 07 to 09 had their zone of diffusion in Andalusia and central Spain. However, a few cultivars from Levante zone also grouped into different clusters; these were 'Argudel' (cluster 07) as

well as 'Callosina' and 'Corbella' (both were included in cluster 09).

Remaining clusters (10 to 13 ) included cultivars from the Levante zone that formed clusters with relatively low values of similarity. Some cultivars from Andalusia ('Amargoso',

Table 2. AMOVA and HOMOVA analysis for the partitioning of RAPD variation in olive varieties among and within Spanish zones (Levante/Central/Andalusia).

\begin{tabular}{lrcccccc}
\hline $\begin{array}{l}\text { Source of } \\
\text { variation }\end{array}$ & df & $\begin{array}{c}\text { Variance } \\
\text { components }\end{array}$ & $\begin{array}{c}\% \text { Total } \\
\text { variance }\end{array}$ & $\begin{array}{c}\phi \\
\text { statistics }\end{array}$ & $\begin{array}{c}P \\
\text { value }\end{array}$ & $\begin{array}{c}\text { Bartlett's } \\
\text { index }\end{array}$ & $\begin{array}{c}P \\
\text { value }\end{array}$ \\
\hline Among zones & 2 & 0.010 & 4.12 & 0.041 & $<0.001$ & 0.342 & $<0.0009$ \\
Within zones & 79 & 0.235 & 95.88 & & & & \\
\hline
\end{tabular}

'Verdial de Velez-Malaga', and 'Lechín de Sevilla') were also grouped in these clusters.

Two cultivars, 'Canetera' and 'Llumeta', both from Levante zone, clustered independently to the dendrogram.

No clear structure for geographic origin for the Andalusian cultivars was found when they were analysed separately from the rest of cultivars under study (data not shown).

AMOVA analysis. Hierarchical analysis of RAPD phenotypic diversity using AMOVA was performed to analyse the partition of RAPD variation in olive varieties among and within Spanish zones (Table 2). Although most of the total genetic diversity was attributable to differences among cultivars within Spanish zones $(95.88 \%)$, significant $\phi$ values among zones $\left(\phi_{\text {st }}=0.041 ; p<0.001\right)$ suggested the existence of phenotypic differentiation. Corresponding HOMOVA analysis revealed that the molecular variances were heterogeneous among zones $\left(\mathrm{B}_{\mathrm{p}}=0.342, p<0.001\right)$. The proportion of diversity attributable to differences between the Andalusian and central zone had negative values $\left(\phi_{\mathrm{st}}=-0.007 ; p=\right.$ $0.644)$. $\phi$ values between each pair of Spanish zones were not significant, except for the pair Andalusia/Levante (Table 3).

\section{Discussion}

RAPD markers used in this study generated a sufficient number of polymorphisms to determine genetic relationships among Spanish olive cultivars. Knowledge of genetic similarity between genotypes facilitates efficient sampling and utilization of germplasm resources. Genetic variability estimated by means of RAPD markers complements agronomic evaluations (del Río and Caballero, 1994) in the selection of optimal cross combinations.

The clustering of the cultivars originating from the same or nearby geographic areas (southern and central Spain) is reasonable, as these zones are close geographically and dispersion between them might have occurred because of lack of geographic barriers. The same clustering tendency for the majority of Levante cultivars at low levels of similarity has been found in previous researches (Belaj et al., 2000, 2001). These results may indicate a different genetic base for the cultivars from Levante and agree with the hypothesis of authochthonous origin as well as the limited diffusion of olive cultivars from their zones of cultivation (Barranco, 1997; Belaj et al., 2000; 2001; Besnard et al., 2001; Rallo and Cidraes, 1978). Sanz-Cortés et al. (2001) also found clustering of cultivars according to their origin at the regional level (Valencia, northeastern

Table 3. Interregional distance matrix ${ }^{z} \phi_{\text {st }}$ among three Spanish zones.

\begin{tabular}{lccc}
\hline Region & Levante & Central & Andalusia \\
\hline Levante & & 0.086 & 0.000 \\
Central & 0.027 & & 0.644 \\
Andalusia & 0.060 & -0.007 & \\
\hline
\end{tabular}

${ }^{2}$ Lower matrix diagonal: $\phi$ value $=$ proportion of the total variance that is partitioned between two regions; upper matrix diagonal $=$ corresponding $p$ values 
Spain). Studies carried out by means of RAPD markers in other Mediterranean countries such as Albania (Belaj et al., 2003) and Syria (Belaj, unpublished data) further support the tendency of cultivars to group according to their zone of diffusion.

Isozyme analysis (Hamrick and Godt, 1989; Lamboy et al., 1996) and RAPD markers (Bartish et al., 2000; Gauer and Cavalli-Molina, 2000; Oraguzie et al., 2001) have shown that, in general, outcrossing species retain most of their genetic variability within populations. We found that within-zone proprtion of total genetic variability for Spanish olive cultivars $(95.88 \%)$ was higher than the between zones component $(4.12 \%)$. This higher within zone variability agrees with the general observation that woody perennial outbreeding species maintain most of their variation within population. The low but significant level of differentiation among different zones $\left(\phi_{\mathrm{st}}=\right.$ $0.041 ; p<0.001)$ also agrees with the hypothetical multilocal selection of olive cultivars (Besnard et al., 2001)

The significance of $\phi_{\mathrm{st}}$ and HOMOVA values between the pair Levante/Andalusia of Spanish zones suggests the presence of differentiation. This result can probably be attributed to the local selection of cultivars for a particular outstanding character and their subsequent vegetative propagation. Geographic distance between these zones might have also influenced the presence of differentiation. The negative value of $\phi_{\mathrm{st}}$ observed in the case of the pair Andalusia/central Spanish olive growing zones suggests that cultivars from central zone are no more likely to be closely related to one another than they are to cultivars from the zone of Andalusia and vice versa. The geographic proximity, lack of geographic barriers and the existence of commercial roads could have helped the exchange of genetic resources between these zones. AMOVA analysis further support the classification of Spanish olive cultivars using Jaccard's coefficient of similarity.

The results of AMOVA analysis indicate that much of the variability present in Spanish olive germplasm can be found among cultivars within a single olive-growing zone. It also indicates that collecting as many distinct cultivars from as many different regions of Spain (Barranco, 1997), can be a good strategy to represent the entire variability of the olive species in this country. Furthermore, the
AMOVA results show that breeders in Spain, as in other Mediterranean countries (Belaj et al., 2002), may rely on the autochthonous olive genetic resources for the design of breeding programs since sufficient genetic variability exists among these cultivars.

\section{Literature Cited}

Barlett, M.S. 1937. Some examples of statistical methods of research in agriculture and applied biology. J. Royal Stat. Soc. Suppl. 4:137-170.

Barranco, D. 1997. Variedades y patrones, p. 59-80. In: D. Barranco, R. Fernández-Escobar, and L. Rallo (eds.). El cultivo del olivo. Mundiprensa y Junta de Andalucía, Madrid, Spain.

Barranco, D. and L. Rallo. 1984. Las variedades de olivo cultivadas en Andalucía. M. ${ }^{\circ}$ de Agricultura, Junta de Andalucía, Madrid, Spain.

Bassam, B.J., G. Caetano-Anollés, and P.M. Gresshoff. 1991. Fast and sensitive silver staining of DNA in polyacrylamide gels. Anal. Biochem. 80:81-84.

Bartish, I.V., L.P. Grakava, K. Rumpunen, and H. Nybom. 2000. Phylogenetic relationships and differentiation among and within populations of Chaenomeles Lindl. (Rosaceae) estimated with RAPDs and isozymes. Theor. Appl. Genet. 101: 554-563.

Belaj, A., I. Trujillo, and L. Rallo. 2000. RAPD analysis support the autochthonous origin of olive cultivars. Proc. $4^{\text {th }}$ Intl. HIS. Symp. Olive Growing, Valenzano, Bari, Italy, Section 1, p. 8.

Belaj A., I. Trujillo, R. de la Rosa, L. Rallo, and M.J. Giménez. 2001. Polymorphism and discriminating capacity of randomly amplified polymorphic markers in an olive germplasm bank. J. Amer. Soc. Hort. Sci. 126:64-71.

Belaj A., Z. Satovic, L. Rallo, and I. Trujillo. 2002. Genetic diversity and relationships in olive (Olea europaea L.) germplasm collections as determined by randomly amplified polymorphic DNA. Theor. Appl. Genet. 105:638-644.

Belaj A., Z. Satovic, H. Ismaili, D.H. Panajoti, L. Rallo, and I. Trujillo. 2003. RAPD genetic diversity of Albanian olive germplasm and its relationships with other Mediterranean countries. Euphytica 130 (3):387-395.

Besnard, G., P. Baradat, and A. Bervillé. 2001. Genetic relationships in the olive (Olea europaed $L$.) reflect multilocal selection of cultivars. Theor. Appl. Genet. 102:251-258.

del Río, C. and J.M. Caballero. 1994. Preliminary agronomical characterization of 131 cultivars introduced in the Olive Germplasm Bank of Cordoba in March 1987. Acta Hort. 356:110-115.

Excoffier, L., P.E. Smouse, and J.M. Quattro. 1992. Analysis of molecular variance inferred from metric distances among DNA haplotypes: application to human mitochondrial restriction sites. Genetics 131:479-491.

Excoffier, L. 1992. WinAMOVA ver 1.55-Analysis of Molecular Variance-Graphical Windows 3.x program for the analysis of population structure from molecular or conventional genetic data http://anthropologie.unige.ch/LGB/software/ win/amova/.

Gauer, L. and S. Cavalli-Molina. 2000. Genetic variation in natural populations of maté (Illex paraguariensis A. St. -Hil., Aquifoliaceae) using RAPD markers. Heredity 84:647-656.

Gustine, D.L. and D.R. Huff. 1999. Genetic variation within and among white clover populations from managed permanent pastures of the northeastern USA. Crop. Sci. 39:524-530.

Hamrick, J.L. and M.J.W. Godt. 1989. Allozyme diversity in plant species, p. 4-63. In: A.H.D. Brown, M.T. Clegg, A.L. Kahler, and B.S. Weir (eds.). Plant population genetics, breeding and genetic resources. Sinauer, Sunderland.

Huff, D.R. 1997. RAPD characterization of heterogeneous perennial ryegrass cultivars. Crop. Sci. 37:557-564.

Jaccard, P. 1908. Nouvelle recherches sur la distribution florale. Bul. Soc. Vaud. Sci. Nat. 44: 223-270.

Lamboy, W.F. J.Yu, P.L. Forsline, and N.F. Weeden. 1996. Partitioning of allozyme diversity in wild populations of Malus sieversii L. and implications for germplasm collection. J. Amer. Soc. Hort. Sci. 121:982-987.

Mantel, N. 1967. The detection of disease clustering and a generalized regression approach. Cancer Res 27:209-220.

Oraguzie, N.C., S.E. Gardiner, C.M. Basset, M. Stefanati, R.D. Ball, V.G. M. Bus, and A.G. White, 2001. Genetic diversity and relationships in $M a$ lus sp. germplasm collections as determined by randomly amplified polymorphic DNA. J Amer Soc Hort Sci 126:318-328.

Rallo, L. and F. Cidraes. 1978. Mejora vegetal del olivo. II Seminario Oleícola Internacional. Ministerio de Agricultura, Madrid, Spain. p. 26-43.

Rohlf, F.J., 1998. NTSYS-pc. Numerical axonomy and multivariate analysis system. version 2.00. Exeter Software, Setauket, N.Y.

Sanz-Cortés, F., M.L. Badenes, S. Paz, A. Iñiguez, and G. Llácer. 2001. Molecular characterization of olive cultivars using RAPD markers. J. Amer. Soc. Hort. Sci. 126:7-12.

Stewart, C.N. and L. Excoffier. 1996. Assessing population structure and variability with RAPD data: Application to Vaccinium macrocarpon (American cranberry). J. Evol. Biol. 9:153-171.

Trujillo, I. 1992. Identificación y clasificación de cultivares de olivo (Olea europaea L. ) por análisis de isoenzimas. Tesis doctoral. Universidad de Córdoba.

Trujillo, I., L. Rallo, and P. Arus 1995. Identifying olive cultivars by isozyme analysis. J. Amer. Soc. Hort. Sci. 120:318-324. 